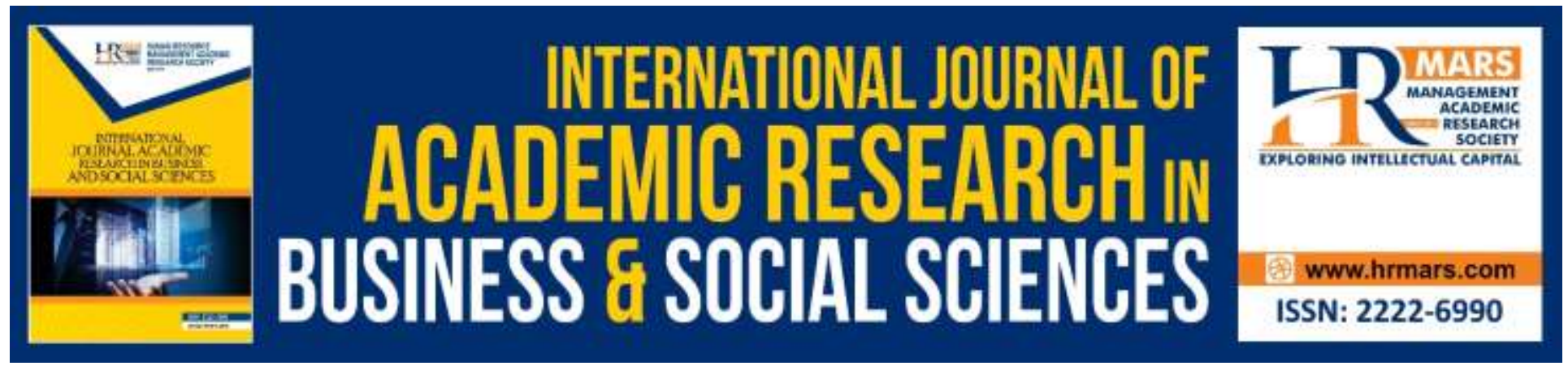

\title{
Knowledge Sharing Behavior of Multiracial Staff Engaged in Industrial Firms of Islamabad, Pakistan
}

\author{
Irfan Raza, Abdul Rehman Chaudhry, Zainudin Awang
}

To Link this Article: http://dx.doi.org/10.6007/IJARBSS/v9-i11/6636

DOI: 10.6007/IJARBSS/v9-i11/6636

Received: 12 November 2019, Revised: 24 November 2019, Accepted: 30 November 2019

Published Online: 19 December 2019

In-Text Citation: (Raza, Chaudhry, \& Awang, 2019)

To Cite this Article: Raza, I., Chaudhry, A. R., Awang, Z. (2019). Knowledge Sharing Behavior of Multiracial Staff Engaged in Industrial Firms of Islamabad, Pakistan. International Journal of Academic Research in Business and Social Sciences, 9(11), 1073-1085.

\section{Copyright: @ 2019 The Author(s)}

Published by Human Resource Management Academic Research Society (www.hrmars.com)

This article is published under the Creative Commons Attribution (CC BY 4.0) license. Anyone may reproduce, distribute, translate and create derivative works of this article (for both commercial and non-commercial purposes), subject to full attribution to the original publication and authors. The full terms of this license may be seen at: $\underline{\text { http://creativecommons.org/licences/by/4.0/legalcode }}$

Vol. 9, No. 11, 2019, Pg. 1073 - 1085

Full Terms \& Conditions of access and use can be found at http://hrmars.com/index.php/pages/detail/publication-ethics 


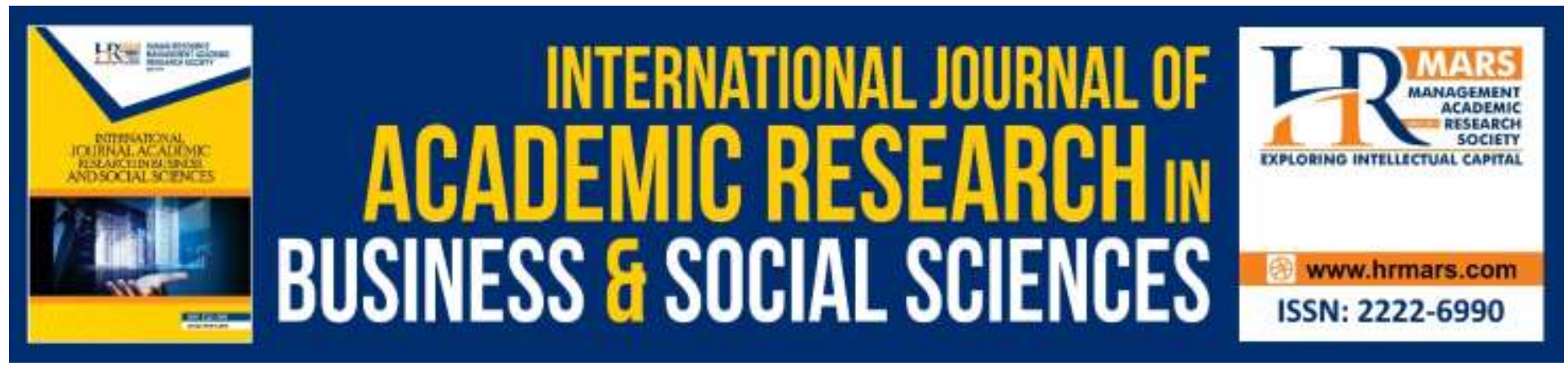

\title{
Knowledge Sharing Behavior of Multiracial Staff Engaged in Industrial Firms of Islamabad, Pakistan
}

\author{
Irfan Raza \\ Faculty of Economics and Management Science, Universiti Sultan Zainal Abidin (UniSZA), \\ Malaysia \\ Mail: iraza@numl.edu.pk
}

\begin{abstract}
Abdul Rehman Chaudhry
Assistant Professor, National University of Modern Languages-NUML, Islamabad, Pakistan
\end{abstract}

\section{Prof. Dr. Zainudin Awang}

Faculty of Economics and Management Science, Universiti Sultan Zainal Abidin (UniSZA), Malaysia

\begin{abstract}
Intercultural knowledge sharing should be more valuable than knowledge sharing in a more homogenous group. Employees recruited from different parts of the world have different perspectives and possess different knowledge resources. The assurance that valid information can flow freely between co-workers is critical for a successful operation in an organization. Conversely, lack of trust among co-workers may seriously hamper sharing of important information, potentially damaging the effectiveness of business processes. This study checked the effect of cultural diversity management on knowledge sharing behavior of multiracial employees working in 4 industrial firms of Islamabad, Pakistan. Moreover interpersonal trust among employees was considered as mediator between relationship of cultural diversity management and knowledge sharing behavior. Convenient sampling technique was applied with a sample size of 256 respondents, whereas, thirty one likert-type questions were used to collect responses with $\alpha=0.853$. The results demonstrate that cultural diversity management has a significant positive effect on employee knowledge sharing. In addition, interpersonal trust partially mediated the relationship between cultural diversity management and knowledge
\end{abstract}


sharing. There were significant managerial implications which were briefly described in last part of the study.

Keywords: Cultural Diversity Management, Interpersonal Trust, Multicultural Staff, Knowledge Sharing.

\section{Introduction}

Business competition becomes more vigorous and local firms adopt international HR practices, and the company leaders search for less expensive and competitive workforce who can reduce cost and provide maximum productivity. All this leads to an increase in local and international diversified work force (Marques, 2008). Diversity management is significant nowadays. The reason behind this is that as social interaction and communication increased, global boundaries are reduced and international firms step up in different countries (D'Netto \& Sohal, 1999). Carrell et al. (2006) explain workforce diversity as people differ in terms of age, gender, race, education, religion and culture; and this difference affect their tasks and relationships while working in an organization.

Shen et al. (2014) suggest that there is a need to conduct a study on how cultural diversity management are effecting on employee knowledge sharing behavior. In Pakistan, researchers argue that HR practices are Hukou-based (original from china, rural migrated to urban after 1949 reform) (Chan \& Li, 1999). Pakistani system is same as Hukou-based because the context is somewhat same. In other countries where people are discriminated not only on the bases of backgrounds, race, gender and age but on bases of hukou as well (Shen et al., 2014). In Pakistan, like China, people are migrated from rural to urban areas in search of jobs and occupations but they are being discriminated on the bases of wage, training, promotion, welfare and social insurance, so cultural diversity management in Pakistan need to comprehend the inequality between rural and urban workforce. Study mainly focuses to examine the effect of cultural diversity management on employee knowledge sharing behavior with mediating role of interpersonal trust.

\section{Problem Statement}

According to a recent study Pakistan is a highly diverse state with regard to cultural practices, religion, language, ethnicity and other attributes (Syed, 2008). In the current scenario of Pakistan organizations have a diversified force than ever before. In result organizations are facing lots of problems due to non-existence or in-adequate implementation of policies related to management of workforce diversity (Idrees et al., 2013; Afzal et al., 2013).

In Pakistan, many research studies have been conducted focusing the direct effect of workforce diversity on knowledge sharing and working relation (Maham, 2013), employee performance (Mushtaq et al., 2015; Rizwan et al., 2016) and organizational performance (Iqbal \& Shah, 2015). Moreover in Pakistan very few studies like (Nadim et al., 2016; Raza \& Tariq, 2016) have been conducted to measure the indirect effect of workforce diversity on organizational outcomes. The present study helps in developing the model for managing workforce diversity to achieve knowledge sharing. 


\section{Research Gap}

There are studies in Pakistani context which have discussed the knowledge sharing behavior of employees engaged in academia, hospitals, banks and industries but discussion of knowledge sharing issues of multiracial industrial staff in Pakistan is limited. Current study has filled the empirical gap exists in literature by exploring KSB of multiracial and multicultural employees working in business sector of Pakistan.

\section{Significance of the Study}

The study will help to understand how cultural diversity management (equal employment opportunity, equality in training and development, reward, promotion, performance assessment etc.) will be helpful to reshape individual behavior and perception about knowledge sharing. It will also supportive for organizations to encourage and develop a learning environment where people are willing to share their knowledge and they have a trust on their leadership, which will ultimately facilitate organizations in increasing their productivity and performance.

\section{Literature Review}

\section{Cultural Diversity Management}

Cultural diversity management is concerned with workplace equality, valuing and making use of a diverse workforce (D'Netto \& Sohal, 1999; Shen et al., 2009). Human Resource (HR) Management consists on the activities and functions which maintain to attract, retain and develop the people within the organization (Lado \& Wilson, 1994). HR Management mainly consists of personnel recruitment, training and development, performance review and reward (Shen et al., 2009). All these practices mainly focus on people's management because ultimately all have to do with humans who are diverse and different from each other. Best results from HR Management practices could be achieved from better management of diversity because it affects individual and organization as a whole (Ehrhart \& Naumann, 2004). It can be said that cultural diversity management does not only minimize the negative effect but it also helps to achieve organizational outcomes by using that workforce effectively (Reskin \& McBrier, 2000).

\subsection{Knowledge Sharing}

Knowledge sharing is a human behavior which can be explained as when individual is willing to share and transfer his/her knowledge to other members. This will lead organization towards improvement of performance and innovation for getting competitive edge (Ipe, 2003). When knowledge sharing culture is prevailed within the organization then people optimistically guide and support to their colleagues (Anand et al., 2010). Researchers suggest that knowledge sharing environment can be promoted by changing individual attitude and behavior rather that by directly measuring or training employees to implement their business strategies (Bock \& Kim, 2002).

\section{Interpersonal Trust}

Interpersonal trust is a well-known phenomenon now a days; trust between coworker and manager, even trust on organization is also included in workplace trust terminology (Dirks \& 
Ferrin, 2002). It can be explained that party on whom one person is dependent will pose that behavior which meets all the expectations of a trusty (Martins, 2002). Trust has different attributes and can be found between families and friends, communities and organizations, societies and in nations enlarge (Hardin, 2002; Podsak et al., 2003. Trust on leader is described as people willing to follow blindly and have faith that what so ever a leader is trying to achieve will be in their best interest (Martins, 2002).

\section{Conceptual Frame Work \& Research Hypotheses}

Relationship among all the variables discussed in this study is presented in Figure 1. Cultural diversity management is considered as predictor variable and its impact is checked on employee knowledge sharing which is predicted variable. Interpersonal trust mediates the relationship of predictor and predicted variable.

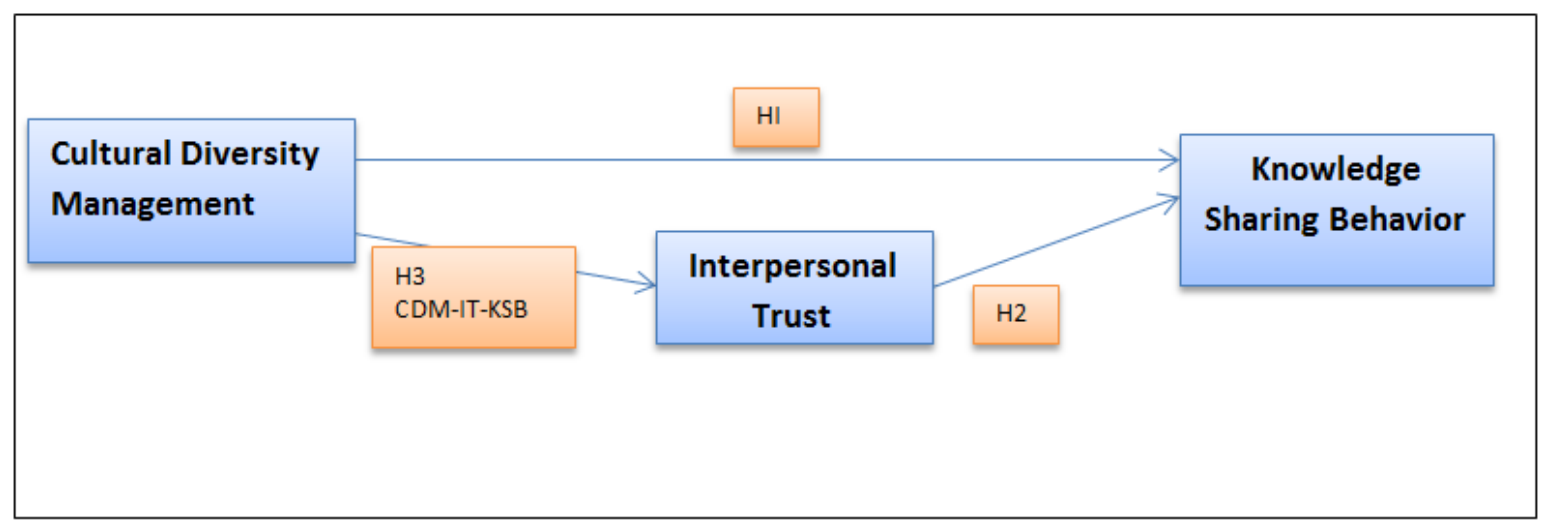

Figure 1: Conceptual Framework

Based on the conceptual framework presented in Figure 1, following research hypotheses are made.

Hypothesis 1: Cultural Diversity Management has significant and positive effect on employee knowledge sharing behavior.

Hypothesis 2: Interpersonal Trust has significant and positive effect on employee knowledge sharing behavior.

Hypothesis 3: Interpersonal Trust mediates the relationship between cultural diversity management and employee knowledge sharing behavior.

\section{Research Methodology \\ Research Design}

The nature of current study is descriptive and casual. The data was collected from four large organizations of Islamabad, Pakistan. Cultural diversity management (CDM) was taken as independent variable and knowledge sharing behavior (KSB) was considered as dependent variable. Interpersonal trust was acted as mediator between CDM and KSB. 
To collect responses from respondents a questionnaire survey was administered. Respondents were asked to give answers on a five point likert scale, with scale anchors ranging from 'strongly disagree' (1) to 'strongly agree' (5). Structured questionnaire was closed ended and splitted into two sections. First section gathered demographic information from respondents which included gender, age, job positions and education. In second section respondents gave responses about the variables of this study. 13 questions were developed for cultural diversity management, 12 questions for knowledge sharing and 6 for interpersonal trust. To give feedback for second section respondents needed to check or tick the particular check boxes of likert scale items.

Questionnaire was sent to different departments included production, human resource, logistic, marketing and finance for getting exact information about cultural diversity management. Both male and female workers were part of sample space possessing different level of educational qualifications. According to nature of job, respondents were categorized into two main clusters: managers and non managers; whereas age ranges of respondents were from 20 years to 60 years.

Development of Measures

CDM was measured with help of HRDM practices $(\alpha=0.89)$ with 13 items scale adopted from (Shen et al., 2014). The included items were providing employment opportunities to rural migrant, equality, providing training and development, compensation and reward with discrimination on the bases of hukou or other characteristics.

Knowledge sharing $(\alpha=0.84)$ scale was adopted from (Bock \& Kim, 2002). Scale consisted of 12 items which was divided into two dimensions. The first dimension is willingness intentions to share knowledge and the second is actual knowledge sharing behavior. First dimension has 5 items and second has 7 items.

Interpersonal Trust $(\alpha=0.83$ ) was measured by using six items adopted from (Podsak et al., 2003). Sample item was 'My leader will never try to deceive worker for gaining any advantage'.

A convenient sampling technique was used to gathered data. There is large amount of population which could cover under the scope of the study so among all convenient sampling was the best suitable. Four large size organizations which are located in Islamabad were selected for survey study. Among them, one is government and other 3 are private organizations. Total 300 questionnaires were distributed but 256 were collected back. So over all response rate was $77 \%$.

Statistical Package for Social Sciences (SPSS) version 20 and Microsoft Excel software tools were used to analyze and interpret data. To check reliability of test instrument Cronbach's Alpha test was applied on responses. Multiple regression and correlation analysis were applied to analyze the relationship between predictor and predicted variables. To test the effect of mediating variable Baron and Kenny (1986) method has been used. 
INTERNATIONAL JOURNAL OF ACADEMIC RESEARCH IN BUSINESS AND SOCIAL SCIENCES

Vol. 9, No. 11, November, 2019, E-ISSN: 2222-6990 ㄷ 2019 HRMARS

\section{Results}

This is a quantitative study and results can be expressed in form of ratios, percentages and tables to give meaningful information of responses collected from respondents.

\section{Demographics}

Table-1: Demographics $(N=256)$

\begin{tabular}{cccc}
\hline & & Frequency & Percentage \\
\hline Age & $20-29$ & 145 & 57 \\
& $30-39$ & 95 & 37 \\
& $40-49$ & 9 & 3 \\
& 50 or above & 7 & 3 \\
& Total & 256 & 100 \\
\hline Gender & Male & 203 & 79 \\
& Female & 53 & 21 \\
& Total & 256 & 100 \\
\hline Education & High school/ & 19 & 7 \\
& diploma & 95 & 37 \\
& Bachelors & 110 & 43 \\
& Masters & 32 & 13 \\
& Post Masters & 256 & 100 \\
\hline Job Position & Total & 156 & 61 \\
& Managerial & 100 & 39 \\
& Non Managerial & 256 & 100 \\
\hline
\end{tabular}

Table-1 depicts the demographics of respondents which include age, gender, educational qualification and job position. According to the results maximum percentage of respondents, having age $20-29$ years, is $57 \%$ whereas minimum percentage is $3 \%$ for age 50 years or above. $79 \%$ male and $21 \%$ female respondents are part of sample whereas education statistics show that $7 \%$ respondents possess high school degree/diploma, 37\% workers have bachelors' degree, $43 \%$ have masters' degree and $13 \%$ respondents are post masters. Job position is categorized at two levels, Manager and Non Manager. 61\% respondents are sitting on managerial positions and $39 \%$ are on non-managerial positions.

Reliability Analysis

Reliability test are used to measure the reliability and internal consistency of items. Consistency of items is measured by Cronbach's Alpha values. 
Table-2 Reliability Statistics

\begin{tabular}{lll}
\hline Variables & Cronbach's $\alpha$ & N of Items \\
\hline CDM & 0.916 & 13 \\
KSB & 0.881 & 12 \\
IT & 0.816 & 6 \\
Overall & 0.853 & 31 \\
\hline
\end{tabular}

Smallbone and Quinton (2004) mention that better reliability score is somewhere between 0.7 to 0.9. Pilot study was made on 35 respondents and reliability results are reported. Cronbach's Alpha results of all variables mentioned in Table- 2 are more than 0.7 which show a solid reliability of test instrument.

\section{Mean, Standard Deviation and Pearson's Correlation}

Table-3 presents the mean, standard deviation and correlation analysis of all variables which are part of current study. There is significant positive correlation observed between CDM and employee knowledge sharing $\left(r=0.737^{* *}\right.$, significant at $\left.1 \%\right)$. The positive interaction shows that if somewhat decent diversity management practices prevailed in organization then employees will tend to show more knowledge sharing behavior. Interpersonal Trust also has significant correlation with employee knowledge sharing $\left(r=0.644^{* *}\right.$, significant at $\left.1 \%\right)$, hence if there exists Interpersonal Trust in the organization then people will tend to show more knowledge sharing intentions. There is also significant linear relationship between CDM and Interpersonal Trust ( $r=$ $0.639 * *$, significant at $1 \%$ ) which shows better CDM practices make confidence and trust on upper management. Table-3 also presents mean and standard deviation values, which depict the agreeable trend of most respondents. Hence it can be inferred that for those organizations which have better cultural diversity management, their employees like to share their knowledge with other employees and have Interpersonal Trust.

Table-3: Mean, Standard Deviation and Correlation Scores

\begin{tabular}{llllll}
\hline & Mean & S.D & CDM & KSB & IT \\
\hline HRDM & 3.9303 & .59960 & 1 & & \\
KSB & 3.6374 & .62196 & $.737^{* *}$ & 1 & \\
IT & 3.8247 & .64132 & $.639^{* *}$ & $.644^{* *}$ & 1 \\
\hline
\end{tabular}

\section{Empirical Hypotheses Testing}

Multiple and step-wise regression analysis was used for empirical hypotheses testing. For hypothesis-1 and hypothesis-2 linear regression has been used, whereas for hypothesis-3 mediation analysis with the help of Baron and Kenny (1986) has been conducted.

Testing of Hypothesis-1

For checking the Effect of CDM on knowledge sharing linear regression test has been conducted. Since Table- 4 has shown that there is significant positive relation exists between the 
two variables it also means that one variable has significant effect on other variable (hypothesis1)

Table-4 Linear Regression Analysis ( $N=256)$

\begin{tabular}{llllll}
\hline & \multicolumn{3}{l}{ Unstandardized Coefficients } & & \multicolumn{2}{l}{ Standardized Coefficients } \\
\cline { 1 - 3 } Variable & $B$ & Std. Error & $T$ & \\
\hline (Constant) & 0.632 & 0.1753 & .615 & \\
\hline CDM & 0.765 & 0.044 & 17.389 & $0.737^{*}$ \\
\hline IT & 0.624 & 0.047 & 13.408 & $0.644^{*}$ \\
\hline
\end{tabular}

Note. $R=0.737 ; R^{2}=.543 ;$ Adjusted $R^{2}=0.542 ; F(1,254)=302.368 ;{ }^{*} p<0.05$

Table-4 demonstrates that cultural diversity management significantly affects $\mathrm{KSB}=0.765, \mathrm{t}=$ $17.389, p<0.05$. Standardized coefficient $\beta=0.737, p<0.05$ shows that hypothesis -1 , Cultural diversity management has positive and significant impact on knowledge sharing behavior, has been accepted. Interpersonal trust significantly affects $K S B=0.624, t=13.408, p<0.05$. Standardized coefficient $\beta=0.644, p<0.05$ shows that hypothesis-2, interpersonal trust has significant and positive effect on knowledge sharing behavior, has been accepted.

Testing of Hypothesis-3

Table- 5 presents the statistical results of mediation role of interpersonal trust between cultural diversity management and employee knowledge sharing.

Table-5: Mediation Analysis using Baron and Kenny (1986) ( $N=256)$

\begin{tabular}{|c|c|c|c|c|c|c|c|}
\hline Variable & $R^{2}$ & $\begin{array}{l}\text { Adjusted } \\
R^{2}\end{array}$ & $F$ & $B$ & SEB & $T$ & $\beta$ \\
\hline Step 1: CDM (IV) ? KSB(DV) & 0.543 & 0.542 & 302.368 & 0.765 & 0.044 & 17.389 & $0.737^{*}$ \\
\hline Step 2: CDM (IV) ? IT(MV) & 0.409 & 0.406 & 175.466 & 0.684 & 0.052 & 13.246 & $0.639 *$ \\
\hline Step 3: IT (MV) 国 KSB (DV) & 0.414 & 0.412 & 179.779 & 0.624 & 0.047 & 13.408 & $0.644^{*}$ \\
\hline \multicolumn{8}{|l|}{ Mediation } \\
\hline $\begin{array}{l}\mathrm{H} 1 \\
\text { CDM (IV) }\end{array}$ & 0.594 & 0.591 & 184.935 & 0.571 & 0.054 & 10.57 & 0.551 \\
\hline KSB (DV) & & & & & & & \\
\hline IT (MV) & & & & 0.283 & 0.051 & 5.6 & 0.292 \\
\hline
\end{tabular}

$* \mathrm{p}<0.05$

Results reported in Table-5 show that all assumptions of Baron and Kenny (1986) are proved. First Assumption is that there must present a significant association between independent variable and dependent variable (CDM and knowledge sharing), as CDM is significantly predicting KSB. The equation is (KSB) $0.765(0.044), t=17.389, \beta=0.737, p=0.000$. The second assumption is that CDM should significantly predict Interpersonal Trust. Equation from Table-5 is derived as, (CDM) 0.684(0.052), $t=13.246, \beta=0.639, p=0.000$. The assumption three is that mediating variable should significantly predict dependent variable so here for IT and 
knowledge sharing the equation is, (IT) 0.62(0.047), $t=13.246, \beta=0.639, p=0.000$. Step four of Baron and Kenny (1986) is conducted with help of simple regression. Results reported that Interpersonal Trust is significantly predicting knowledge sharing and equation for this is (CDM) $0.571(0.054), t=10.57, \beta=0.551$. There is significant raise in adjusted $R^{2}$ which increases from 0.542 to 0.591 . It can be explained as interpersonal trust partially mediates the relationship of CDM and KSB.

\section{Discussion and Conclusion}

This is a quantitative study and questionnaire was used to gather responses from two hundred and fifty six respondents who belonged to four business firms of Islamabad. Respondents were categorized according to their gender, age, educational skills and job position in firm (as reported in Table-1). This study explored the effect of cultural diversity management on employee knowledge sharing behavior. Interpersonal trust was used as mediating variable between cultural diversity management and employee knowledge sharing. Study also included different fundamental, social and psychological procedures for measuring effect on knowledge sharing. The findings of current study stated that cultural diversity management was significantly and positively associated with employee knowledge sharing behavior (Table-4). Baron and Kenny (1986) technique was applied to judge the mediation impact. According to results reported in Table-5, interpersonal trust partially mediated the relation between CDM and KSB. These findings provided significant evidence that CDM through HRDM and knowledge sharing had positive and direct relationship, and it was observed that different social and psychological processes effected knowledge sharing behavior of employees.

\section{Contribution of Current Study Contribution to Practice}

Business now-a-days is facing more pressure from diversity related issue. Better and effective management of diversity is unavoidable for survival in this intensive competitive era. This study gives guidelines to top management of business firms having diverse workforce to create a convenient knowledge sharing environment and maintain harmony among employees. in addition, this study provides a tested framework that how CDM through HRDM, interpersonal trust have a significant effect on employee knowledge sharing. For learning and innovation this frame work is very helpful.

\section{Contribution to Theory}

- This study contributed in existing literature by examining the effect of cultural diversity management on knowledge sharing behavior of multicultural employees employed in business firms in Pakistan; moreover assessed the mediating role of interpersonal trust between CDM and KSB.

- Current study is providing a roadmap of the link between CDM and KSB. 
- Establishment of KS behavior of multicultural employees working in large business firms operating in industrial zone of Islamabad, Pakistan made a significant contribution in current literature.

5.2 Limitations of Study

This study has potential limitations which are:

- Organizations which are situated only in Islamabad are considered in this study. Responses from one city are not enough for generalizability of the results.

- There are many other control variables which are not included in this study. For example, in context of Pakistan, language and ethnic background could be taken as control variables.

- This study has not explored all dimensions of trust and knowledge sharing, such as trust on colleagues, trust on system (Whitener, 1997) etc. These factors can be considered as predictors of trust and knowledge sharing. So, in future, there is need to develop more extensive model by using all predictors of employee knowledge sharing.

\section{References}

Afzal, F., Mahmood, K., Samreen, F., Asim, M., \& Sajid, M. (2013). Comparison of workforce diversity in public and private business organizations. Information and Knowledge Management. 3(2), 191-195

Anand, S., Vidyarthi, P. R., Liden, R. C., \& Rousseau, D. M. (2010). Good citizens in poor-quality relationships, idiosyncratic deals as a substitute for relationship quality. Academy of Management Journal, 53(5), 970-988.

Baron, R. M., \& Kenny, D. A. (1986). The moderator-mediator variable distinction in social psychological research: Conceptual strategic and statistical considerations. Journal of Personality and Social Psychology, 51(6), 1173-1182.

Bock, G. W. \& Kim, Y. G. (2002). Breaking the myths of rewards: an exploratory study of attitudes about knowledge sharing. Information Resources Management Journal, 15 (2), 14-21.

Carrell, M. R., Mann, E. E., \& Sigler, T. H. (2006). Defining workforce diversity programs and practices in organizations: A longitudinal study. Labor Law Journal, 57(1), 5-12.

Chan, K. W., \& Li, Z. (1999). The hukou system and rural-urban migration in China: processes and changes. The China Quarterly, 160, 818-855.

Dirks, K. T., \& Ferrin, D. L. (2002).Trust in leadership: meta-analytic findings and implications for research and practice. Journal of Applied Psychology, 8(4), 611-628.

D’Netto, B., \& Sohal, A. S. (1999). Human resource practices and workforce diversity: an empirical assessment. International Journal of Manpower, 20(8), 530-547.

Ehrhart, M. G., \& Naumann, S. E. (2004). Organizational citizenship behavior in work groups: a group norms approach. Journal of Applied Psychology, 89(6), 960-974.

Fishbein, M., \& Ajzen, I. (1975). Belief, Attitude, Intention, and Behavior: An Introduction to Theory and Research, Reading. MA: Addison-Wesley.

Forsyth, D. (1999). Group Dynamics Pacific Grove, CA: Ed (3) Brook/Cole Publishing. 
George, J. M., \& Jones, G. H. (1997). Experiencing work: values, attitudes, and moods. Human Relations, 50(4), 393-416.

Hardin, R. (2002). Trust and Trustworthiness, New York: Russell Sage Foundation 2.

Idrees, R. N., Abbasi, A. S., \& Waqas, M. (2013). Systematic review of literature on workforce diversity in Pakistan. Middle-East Journal of Scientific Research, 17(6), 780-790.

Iqbal, H, S, \& Shah, F, M. (2015). Impact of workforce diversity on organizational performance in the education sector of Karachi. International Journal of Scientific \& Engineering Research, 6(10) 1258-1273.

Ipe, M. (2003). Knowledge sharing in organizations: a conceptual framework. Human Resource Development Review, 2(4), 337-359.

Kreitz, P. A. (2009). Leadership and emotional intelligence: A study of university library directors and their senior management teams. College \& Research Libraries, 70(6), 531-554.

Lado, A. A., \& Wilson, M. C. (1994). Human resource systems and sustained competitive advantage: A competency-based perspective. Academy of Management Review, 19(4), 699-727.

Maham, R. (2013). To recognize cultural diversity that influences knowledge sharing in an organization. International Review of Management and Business Research, 2(4), 1092.

Martins, N. (2002). A model for managing trust. International Journal of Manpower, 23(2), 754769.

Marques, J. F. (2008). Spiritual performance from an organizational perspective: The Starbucks way. Corporate Governance, 8(3), 248-257.

Mushtaq, A., Haider, N., \& Khan, M. (2015). Work force diversity as a source of innovation in context of telecom sector in Pakistan. Journal of Business and Management Research. 8, 205-216

Nadim, M., Hussain, S., Naveed, A., \& Shafique, I. (2016). Diversity management, organizational flexibility and service quality: A study of hospitality industry of Pakistan. International Journal of Research in Education and Social Science, 1(3), 16-26.

Olson, M. (1965). The Logic of Collective Action: Public Goods and The Theory of Groups, Cambridge, MA: Harvard University Press.

Podsakoff, P. M., MacKenzie, S. B., Lee, J. Y., \& Podsakoff, N. P. (2003). Common method biases in behavioral research: $A$ critical review of the literature and recommended remedies. Journal of Applied Psychology, 88(5), 879-903.

Raza, I., \& Tariq, F. (2016). Effect of HR diversity management practices on employee knowledge sharing: Examining the mediating role of trust on leadership and moderating role of cooperative norms. Journal of Business Studies, 12(1).

Rizwan, M., Khan, M. N., Nadeem, B., \& Abbas, Q. (2016). The Impact of workforce diversity towards employee performance: Evidence from banking sector of Pakistan. American Journal of Marketing Research, 2(2), 53-60.

Reskin, B. F., \& McBrier, D. B. (2000). Why not ascription? Organizations' employment of male and female managers. American Sociological Review, 65(2), 210-233. 
Smallbone, T., \& Quinton, S. (2004). Increasing business students' confidence in questioning the validity and reliability of their research. Electronic Journal of Business Research Methods, 2(2), 153-162.

Shen, J., Chanda, A., D'Netto, B., \& Monga, M. (2009). Managing diversity through human resource management: An international perspective and conceptual framework. The International Journal of Human Resource Management, 20(2), 235-251.

Shen, J., D'Netto, B., \& Tang, J. (2014). Effects of cultural diversity management on OCB in China. International Journal of Human Resource Management, 21(2), 2152-2168.

Syed, J. (2008). The representation of cultural diversity in Urdu-language newspapers in Pakistan: A study of Jang and Nawaiwaqt. Journal of South Asian Studies, 31(2), 317-347

Whitener, E. M. (1997). The impact of human resource activities on employee trust. Human Resource Management Review, 7(4), 389-404. 